\title{
THE GHOST IN THE CELLARAGE
}

It has been thought that the whole of the last part of I. v., from the entrance of Horatio and Marcellus, follows the old play closely, and that Shakespeare is condescending to the groundlings.

Here again, whether or no he took a suggestion from the old play, I see no reason to think that he wrote down to his public. So far as Hamlet's state of mind is concerned, there is not a trace of this. Anyone who has a difficulty in understanding it should read Coleridge's note. What appears grotesque is the part taken by the Ghost, and Hamlet's consequent removal from one part of the stage to another. But, as to the former, should we feel anything grotesque in the four injunctions 'Swear!' if it were not that they come from under the stage - a fact which to an Elizabethan audience, perfectly indifferent to what is absurdly called stage illusion, was probably not in the least grotesque? And as to the latter, if we knew the Ghost-lore of the time better than we do, perhaps we should see nothing odd in Hamlet's insisting on moving away and proposing the oath afresh when the Ghost intervenes.

But, further, it is to be observed that he does not merely propose the oath afresh. He first makes Horatio and Marcellus swear never to make known what they have seen. Then, on shifting his ground, he makes them swear never to speak of what they have heard. Then, moving again, he makes them swear that, if he should think fit to play the antic, they will give no sign of knowing aught of him. The oath is now complete; and, when the Ghost commands them to swear the last time, Hamlet suddenly becomes perfectly serious and bids it rest. [In Fletcher's Woman's Prize, v. iii., a passage pointed out to me by Mr. C. J. Wilkinson, a man taking an oath shifts his ground.] 